\title{
Expression of Neuropeptide $Y$ and Neuropeptide $Y(Y 1)$ Receptor mRNA in Rat Spinal Cord and Dorsal Root Ganglia following Peripheral Tissue Inflammation
}

\author{
Ru-Rong Ji, ${ }^{1}$. Zhang, ${ }^{1}$ Z. Wiesenfeld-Hallin, ${ }^{2}$ and T. Hökfelt ${ }^{1}$ \\ 'Department of Neuroscience, Karolinska Institute, S-17177 Stockholm, Sweden and 2Department of Laboratory Medical \\ Science and Technology, Section of Neurophysiology, Huddinge University Hospital, Stockholm, Sweden S-17177
}

By using in situ hybridization histochemistry and immunohistochemistry, neuropeptide $Y$ (NPY) and NPY (Y1) receptor mRNA as well as NPY-like immunoreactivity were examined in the lumbar spinal cord (L4-L5) and in dorsal root ganglia (DRG, L5) in rats injected with complete Freund's adjuvant (CFA) into the hindpaw. A rapid and marked increase in NPY mRNA expression was observed in ipsilateral dorsal horn neurons $6 \mathrm{hr}$ after inoculation as compared to the contralateral side. This was mainly found in the medial part of spinal lamina II. The peak level ( $88 \%$ increase) was reached at 3 d. In adjacent sections of the spinal cord, $96 \%$ and $33 \%$ increases were found in the number of dynorphin and enkephalin mRNA-positive neurons, respectively. Unilateral inflammation also induced a moderate increase in NPY-like immunoreactivity and the number of NPY-immunoreactive neurons in the medial part of the ipsilateral spinal dorsal horn. In addition, a marked elevation in the expression of c-Fos-like protein was observed in ipsilateral spinal neurons in laminae I, II, and V. However, no NPY mRNA-positive or NPY-immunoreactive neurons were found in the ipsilateral and contralateral DRGs in rats receiving CFA injection. Furthermore, a marked upregulation of NPY (Y1) receptor mRNA expression was detected in the ipsilateral spinal dorsal horn $1 \mathrm{~d}$ and $3 \mathrm{~d}$ after inoculation. These $\mathrm{Y}_{1}$ receptor mRNApositive cells were malnly distributed in the medial laminae II and III. Numerous Y1 mRNA-positive, small neuron profiles were found bilaterally in the DRGs in CFA-treated rats. CFA evoked a $34 \%$ increase in the number of $Y 1$ mRNA-positive neurons in ipsilateral DRGs as compared to contralateral DAGs. The distinct upregulation of NPY and NPY (Y1) receptor in response to peripheral inflammation suggests an involvement of NPY in the response to inflammation and in nociception.

[Key words: pain, plasticity, sensory neurons, in situ hybridization, immunohistochemistry]

\footnotetext{
Received Dec. 20, 1993; revised Apr. 5, 1994; accepted Apr. 13, 1994.

This work is supported by the Swedish MKC (04X-2887), the Bank of Sweden Tercentenary Foundation, Marianne and Marcus Wallenbergs Stiftelse and Gustav V:s and Drottning Victorias Stiftelse. We thank Dr. J. Walsh, CURE/UCLA DDC Antibody Core (NIH Grant DK 17294) for generous supply of NPY antiserum, and Dr. M. J. Iadarola, NIH, Bethesda, MD for generous supply of Fos antiserum. Correspondence should be addressed to Dr. Ji Ru-Rong, Department of Neuroscience, Karolinska Institute, Box 60 400, S-17177 Stockholm, Sweden.

Copyright (C) 1994 Society for Neuroscience $0270-6474 / 94 / 146423-12 \$ 05.00 / 0$
}

Injection of complete Freund's adjuvant (CFA), carrageenan, formalin, or other irritative chemicals into the hindpaw of the rat produces an intense inflammation characterized by erythema, edema, and hyperthermia that is limited to the injected paw (Iadarola et al., 1988; Dubner and Ruda, 1992; Solodkin et al., 1992; Weihe et al., 1993). Inflammatory tissue produces an increased sensitivity to noxious stimulation (hyperalgesia), and even innocuous stimuli are often perceived as painful. Accompanying these behavioral changes are alterations in the discharge properties of afferent fibers and neurons in the CNS (Neugebauer and Schaible, 1990; Dubner and Ruda, 1992), as well as changes in levels of messenger molecules. Thus, it has been shown that peripheral inflammation induces upregulation of the synthesis of opioid peptides (Iadarola et al., 1988; Noguchi et al., 1988; Ruda et al., 1988; see also Dubner and Ruda, 1992; Weihe et al., 1993), substance P (SP) (Noguchi et al., 1988), calcitonin gene-related peptide (CGRP) (Hanesch et al., 1993), glutamate (Sluka et al., 1992), NADPH-diaphorase (Solodkin et al., 1992), GABA (Castro-Lopes et al., 1992), and galanin (Tokunaga et al., 1992). Unilateral inflammation also evokes an increase in the dorsal horn expression of c-fos proto-oncogene (Hunt et al., 1987; Presley et al., 1990; Noguchi et al., 1991; Hylden et al., 1992; Leah et al., 1992).

With the recent cloning of an increasing number of neuropeptide receptor genes (Meyerhof et al., 1993), it is now possible to determine the site of synthesis of these receptors at the cellular level. Indeed, inflammation has been shown to induce an elevation in the expression in neurokinin-1 (NK1) receptor (Schäfer et al., 1993). Furthermore, the synthesis of neuropeptide processing enzymes is also altered (Weihe et al., 1993). Regarding neuropeptides, perhaps the most striking example is the increase in dynorphin in local dorsal horn neurons (Dubner and Ruda, 1992; Hylden et al., 1992; Parker et al., 1993).

Ncuropeptide Y (NPY), a 36 amino acid peptide originally isolated from porcine brain (Tatemoto, 1982; Tatemoto et al., 1982), is an important regulatory molecule in both the CNS and PNS (see Mutt et al., 1989; Allen and Koenig, 1992; Dumont et al., 1992). NPY belongs to a family of peptides also including pancreatic polypeptide (PP) (Lin and Chance, 1974; Kimmel et al., 1975) and peptide YY (PYY) (Tatemoto, 1982; Tatemoto et al., 1982). At least two major subtypes of NPY receptors, Y1 and $Y 2$, seem to exist; the $Y 1$ receptor is considered to be a postjunctional, and the Y2 one a prejunctional receptor (see Wahlestedt and Reis, 1993). More recently, the molecular clon- 
ing of the cDNA sequence of the $\mathrm{Y} 1$ receptor has been reported (Eva et al., 1990; Herzog et al., 1992; Larhammar et al., 1992).

Immunohistochemical studies have shown that NPY is one of the most abundant and widely distributed peptides within the mammalian CNS (Allen et al., 1983; Chronwall et al., 1985; de Quidt and Emson, 1986). One area in which NPY-like immunoreactivity (-LI) occurs in high concentrations is the superficial dorsal horn of the spinal cord, where numerous local neurons are NPY positive (Gibson et al., 1984; de Quidt and Emson, 1986; see also Hökfelt et al., 1981; Hunt et al., 1981a,b). Furthermore, a high density of NPY binding sites has been identified in dorsal root ganglia (DRG) and spinal cord (Walker et al., 1988; Kar and Quirion, 1992). However, NPY cannot be detected in normal DRG neurons (Gibson et al., 1984; Jazin et al., 1993; Zhang et al., 1994), whereas NPY (Y 1) rcceptor mRNA has been shown to be present in many neurons in normal DRGs (Jazin et al., 1993; Zhang et al., 1993). Recently, Wakisaka et al. (1991, 1992; see also Zhang et al., 1993) have shown that there is a dramatic upregulation of NPY in primary sensory neurons after peripheral axotomy. Taken together, these studies suggest involvement of NPY in sensory processing in the dorsal horn of the spinal cord. In the present study, we examined the expression of NPY-LI, NPY mRNA, and NPY (Y1) receptor mRNA in the spinal cord and DRG neurons following peripheral tissue inflammation by means of in situ hybridization and immunohistochemistry.

\section{Materials and Methods}

Induction of inflammation. Twenty-five adult male Sprague-Dawley rats weighing 200-250 gm were anesthetized with sodium pentobarbital (40 $\mathrm{mg} / \mathrm{kg}$, i.p.), and $200 \mu \mathrm{l}$ of a 1:1 emulsion of complete Freund's adjuvant (CFA; Sigma) and saline was injected into the plantar surface of one hindpaw. Control rats received sham injection of saline. Animals were kept in cages (three or four animals in a cage) at an ambient temperature of $20-25^{\circ} \mathrm{C}$ under a $12 / 12 \mathrm{hr}$ light/dark cycle and had free access to food and water. The experiments have been approved by Stockholm norra försöksdjursetiska kommitte and attention was paid to the ethical guidelines for investigation of experimental pain in conscious animals (Zimmermann, 1983).

In situ hybridization histochemistry. After inoculation, the animals were allowed to survive for $6 \mathrm{hr}(n=3), 24 \mathrm{hr}(n=3), 3 \mathrm{~d}(n=4)$, and $7 \mathrm{~d}(n=4)$. Inflammatory and control rats $(n=4)$ were decapitated, and the spinal cord (L4-L5) and ipsi- and contralateral L5 DRGs were rapidly removed and immediately frozen on dry ice. Before sectioning, experimental and control spinal cords and DRGs were, respectively, fused by saline on the same blocks, so that all groups could be processed under the same conditions. Coronal sections (14 $\mu \mathrm{m}$ thick) were cut in a cryostat (Microm, Heidelberg, Germany), thawed onto "ProbeOn" slides (Fisher Scientific, Pittsburgh, PA), and stored in sealed boxes at $-20^{\circ} \mathrm{C}$ until hybridization.

Oligonucleotide probes were synthesized with an Applied Biosystem DNA synthesizer 318A (Foster City, CA) or purchased from Scandinavian Gene Synthesis AB (Köping, Sweden) and purified through NAP25 columns (Pharmacia, Uppsala, Sweden) or OPC-columns (Applied Biosystems). The oligonucleotide for NPY receptor mRNA was complementary to the nucleotides $546-585$ of the rat NPY (Y1) receptor (Eva et al., 1990). Sequences for neuropeptide probes were complementary to nucleotides 1671-1714 of rat NPY mRNA (Larhammar et al., 1987), nucleotides $871-918$ of rat dynorphin mRNA (Civelli et al.,
1985), and nucleotides 322-360 of rat enkephalin mRNA (Howells et al., 1984). The oligonucleotide probes were labeled at the 3' end with $\alpha{ }^{35}$ S-dATP (New England Nuclear, Boston, MA) using terminal deoxynucleotide transferase (Amersham) in a buffer containing $10 \mathrm{mM} \mathrm{CoCl}_{2}$, $1 \mathrm{~mm}$ dithiothreitol (DTT; LKB, Bromma, Sweden), $300 \mathrm{~mm}$ Tris base, and $1.4 \mathrm{M}$ potassium cacodylate $(\mathrm{pH} 7.2)$. Afterward the labeled probes were purified through Nensorb-20 columns (New England Nuclear), and DTT was added to a final concentration of $10 \mathrm{~mm}$. The specific activities obtained ranged from 2 to $4 \times 10^{6} \mathrm{cpm} / \mathrm{ng}$ oligonucleotide.

The present hybridization procedure followed previously published protocols (Schalling, 1990; Young, 1990; Dagerlind et al., 1992). In brief, sections were air dried and directly hybridized, without pretreatment, for $18 \mathrm{hr}$ at $42^{\circ} \mathrm{C}$ in humid chambers. The labeled probe was diluted with hybridization buffer containing 50\% formamide (G.T. Baker Chemicals BW, Deventer, The Netherlands), $4 \times$ SSC $(1 \times$ SSC $=$ $0.15 \mathrm{M} \mathrm{NaCl}, 0.0015 \mathrm{M}$ sodium citrate), $1 \times$ Denhardt's solution $(0.02 \%$ each of polyvinylpyrrolidone, bovine serum albumin, and Ficoll), $1 \%$ sarkosyl ( $N$-lauryl sarcosine; Sigma), 0.02 M phosphate buffer (pH 7.0), $10 \%$ dextran sulfate (Pharmacia, Uppsala, Sweden), $250 \mu \mathrm{g} / \mathrm{ml}$ yeast tRNA (Sigma), $500 \mu \mathrm{g} / \mathrm{ml}$ sheared and heat-denatured salmon testis DNA (Sigma), and $200 \mathrm{~mm}$ DTT, and applied to the slides $\left(10^{6} \mathrm{cpm}\right.$ per $100 \mu \mathrm{l} /$ slide). After hybridization the sections were washed $(4 \times 15$ $\mathrm{min}$ ) in $1 \times \mathrm{SSC}$ at $55^{\circ} \mathrm{C}$, and then cooled to room temperature and dipped twice in distilled water. After dehydration through $60 \%$ and $95 \%$ ethanol, the slides were dried in air and dipped in NTB2 nuclear track emulsion (Kodak, Rochester, NY) diluted 1:1 with distilled water, exposed in the dark at $4^{\circ} \mathrm{C}$ for 4 weeks (peptides) or 6 weeks (NPY receptor). Finally, the slides were developed in D-19 (Kodak) for $3 \mathrm{~min}$, fixed in Kodak 3000A\&B for $6 \mathrm{~min}$, and rinsed for $30 \mathrm{~min}$ in running water. Developed slides were mounted with glycerol, coverslipped, and analyzed in a Nikon Microphot-FX microscope equipped with a darkfield condenser. Suhsequently, the slides were lightly stained with toluidine blue, mounted with Entellan (Merck, Darmstadt, Germany), and reexamined under bright-field conditions.

Immunohistochemistry. Three days after the injection of CFA, both inflammatory $(n=4)$ and control rats $(n=3)$ were deeply anesthetized with sodium pentobarbital $(120 \mathrm{mg} / \mathrm{kg}$, i.p.) and transcardially perfused with $50-100 \mathrm{ml}$ of warm saline, followed by $400 \mathrm{ml}$ of $4 \%$ paraformaldehyde with $0.4 \%$ picric acid in $0.16 \mathrm{M}$ phosphate buffer solution (pH 7.2). The L5 DRGs and the L4 and L5 segments of spinal lumbar enlargement were removed, postfixed in the same fixative for $90 \mathrm{~min}$, and then placed in $10 \%$ sucrose solution at $4^{\circ} \mathrm{C}$ overnight. Tissues were embedded with OCT compound (Tissue Tek, Miles Laboratories, Elkhart, IN), cut coronally in a cryostat at $14 \mu \mathrm{m}$ thickness, and mounted on to gelatin-coated slides. Sections were processed according to the ABC method (Hsu et al., 1981) using a polyclonal NPY antibody (1: 4800; CURE/UCLA DDC Antibody Core, Los Angeles, CA), Fos antibody (1:1000; kindly provided by Dr. Iadarola), and ABC Kit (Vector Labs, Burlingame, CA). The sections were incubated for $36 \mathrm{hr}$ at $4^{\circ} \mathrm{C}$ with the primary antibody, and for $1 \mathrm{hr}$ at $37^{\circ} \mathrm{C}$ with the secondary antibody and subsequent $\mathrm{ABC}$ complex. Finally, the reaction product was visualized with $0.05 \% \mathrm{DAB} / 0.001 \%$ hydrogen peroxide in $0.1 \mathrm{M}$ acetate buffer ( $\mathrm{pH} 6.0$ ) containing $2 \%$ ammonium nickel sulfate for 5 min, and then rinsed in acetate buffer, air dried, dehydrated, and coverslipped.

Quantification. For in situ hybridization, counts were done on the sections stained with toluidine blue. The sections were examined under bright field using a $20 \times$ objective lens. Neurons containing five times more grains than mean background grain densities (signal : noise ratio $>5$ ) were counted as positive neurons. Furthermore, some neurons with signal : noise ratio $>10$ were classified as strongly labeled. Mean background grain densities were determined by averaging grain counts over defined areas of the neuropil devoid of positively labeled cell bodies. In a $100 \mu \mathrm{m}^{2}$ area, they were $2.3 \pm 0.2$ (mean $\left.\pm \mathrm{SEM}\right), 2.3 \pm 0.2,2.1$ \pm 0.1 , and $1.6 \pm 0.1$ for the hybridization of NPY, NPY $(Y 1)$ receptor, enkephalin, and dynorphin mRNAs, respectively.

\footnotetext{
Figure 1. Dark-field micrographs showing the distribution of NPY mRNA-positive neurons in spinal dorsal horn (L4-L5) of control rats (Cont; $a, b)$ and in contralateral $(c, e, g)$ and ipsilateral $(d, f, h)$ spinal dorsal horns of rats subjected to $6 \mathrm{hr}(6 h ; c, d), 1 \mathrm{~d}(1 d ; e, f)$, and $3 \mathrm{~d}(3 d ; g, h)$ of peripheral inflammation. Increasing numbers of strongly labeled positive neurons can be observed in the ipsilateral superficial dorsal horn following inflammation. Asterisks indicate ipsilateral side. Arrowheads point to the positive neurons in lamina II, and the arrow points to a positive neuron in lamina I. Dashed line in $a$ indicates the boundary between gray and white matter in the dorsal horn; in $h$ the boundaries of lamina II are shown. Scale bar, $100 \mu \mathrm{m}$ (for $a-h)$.
} 


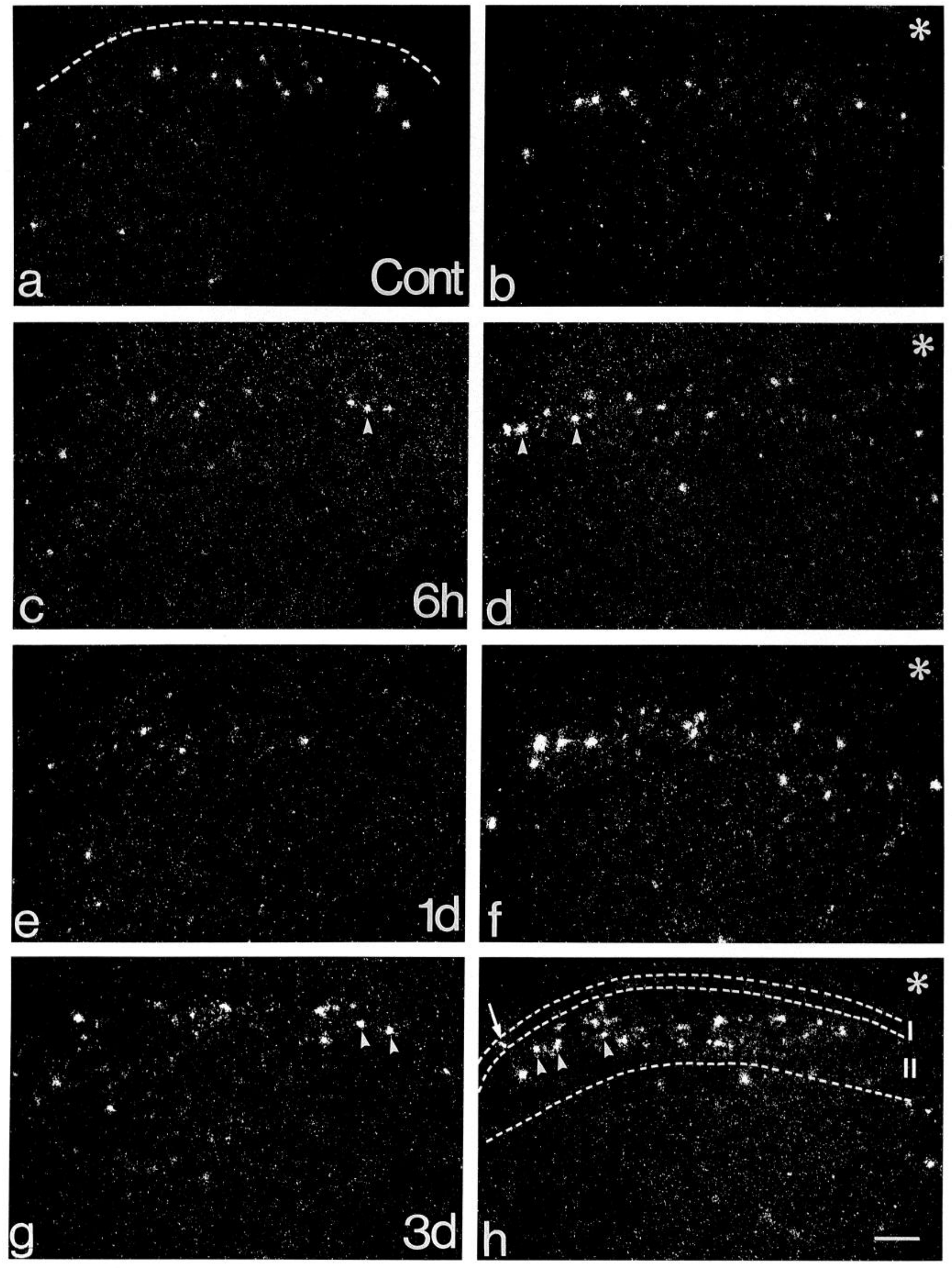




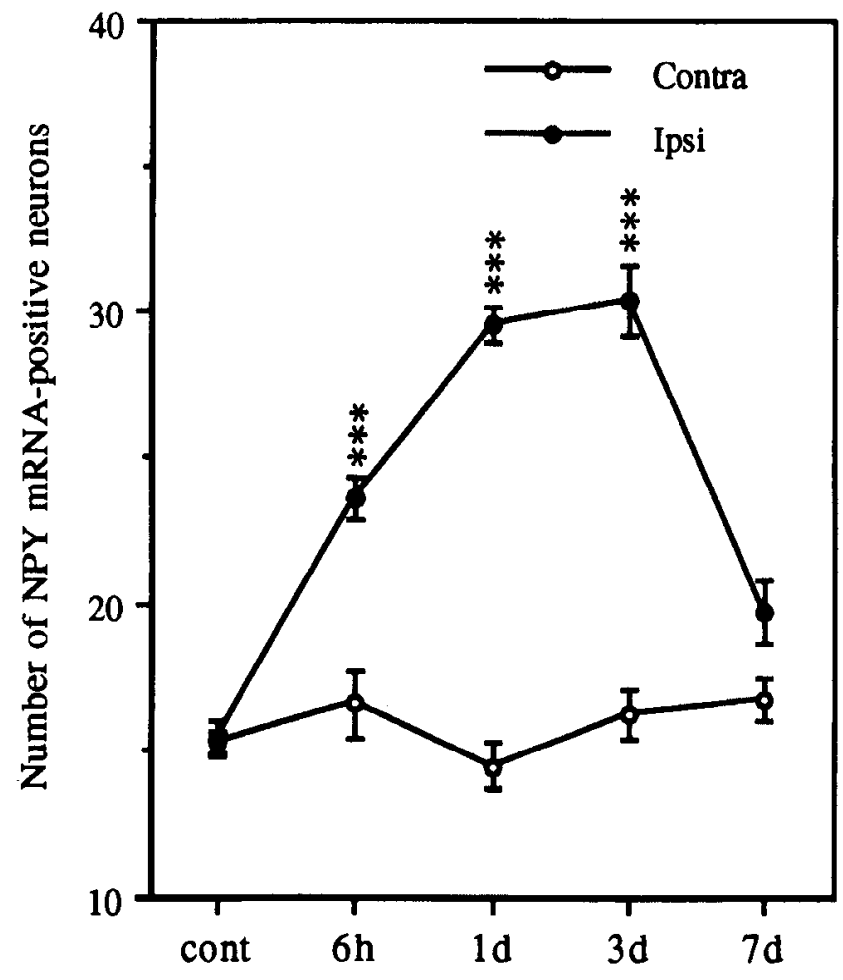

Figure 2. Timc course of changes in the number of neurons expressing NPY mRNA in the spinal dorsal horn (L4-L5) of ipsilateral (Ipsi) and contralateral (Contra) sides after the injection of complete Freund's adjuvant into the hindpaw. The number of neurons per $14-\mu \mathrm{m}$-thick section is expressed as the mean for 12-16 sections taken from three or four rats (four sections/rat) at each time period. The data are represented as mean \pm SEM. cont, control; $d$, day; $h$, hour. ${ }^{* * *}, P<0.001$, paired $t$ test.

mRNA-positive neurons in the spinal cord. Counts from four sections from one animal were averaged as the number of positive neurons for that animal. Three or four CFA-inoculated animals of each time interval and four control rats $(n=4)$ were included.

Percentage of $m R N A$-positive neurons in DRGs. The total number of positive neuron profiles was divided by the total number of toluidine blue-stained neuron profiles in the DRG sections, and the percentage of mRNA-positive profiles was calculated. Percentages of five sections from one animal were averaged as the percentage for that animal. Four rats receiving CFA injection surviving for $3 \mathrm{~d}$ were used for analysis.

Immunoreactivity-positive neurons and fiber network density in the dorsal horn of spinal cord. The total number of positive cells in eight sections ( $14 \mu \mathrm{m}$ thickness) were counted for each rat. Four rats, sacrificed $3 \mathrm{~d}$ after CFA injection, were used for analysis. As shown in Figure $6 a$, the relative immunostaining density level was measured in a $127 \times 76$ $\mu \mathrm{m}^{2}$ area in the medial lamina II of the spinal cord. Twenty sections of spinal cord from four rats were analyzed. The measurements were performed on a Macintosh IIx computer (Apple Computer Inc., Cupertino CA), equipped with a Quick Capture frame grabber board (Data Translation, Marlboro, MA) and a Cage-MTI 72 CCD series camera (DAGEMTI, Michigan City, IN) connected with a Nikon microscope. Image processing was performed with IMAGE software (courtesy by Dr. W. Rasband, NIMH). Each image was digitized with 256 gray levels for each picture element. The density level on the inflammatory side was expressed as percentage of contralateral side, which was set to $100 \%$.

Size of NPY receptor (Y1) $m R N A$-positive neurons in DRGs. By using the above-mentioned program, the size of neuron profiles in DRG sections from control and inflammation animals was measured. For each group 150 neurons of four DRG sections from four rats were measured.

Statistics. All data were assessed using the two-tail paired $t$ test. The criterion for statistical significance was $P<0.05$.

Control experiments. Hybridization control was carried out with an excess of cold probc (100-fold) together with the labeled probe. The specificity of immunostaining was tested by preabsorbing the anti-NPY

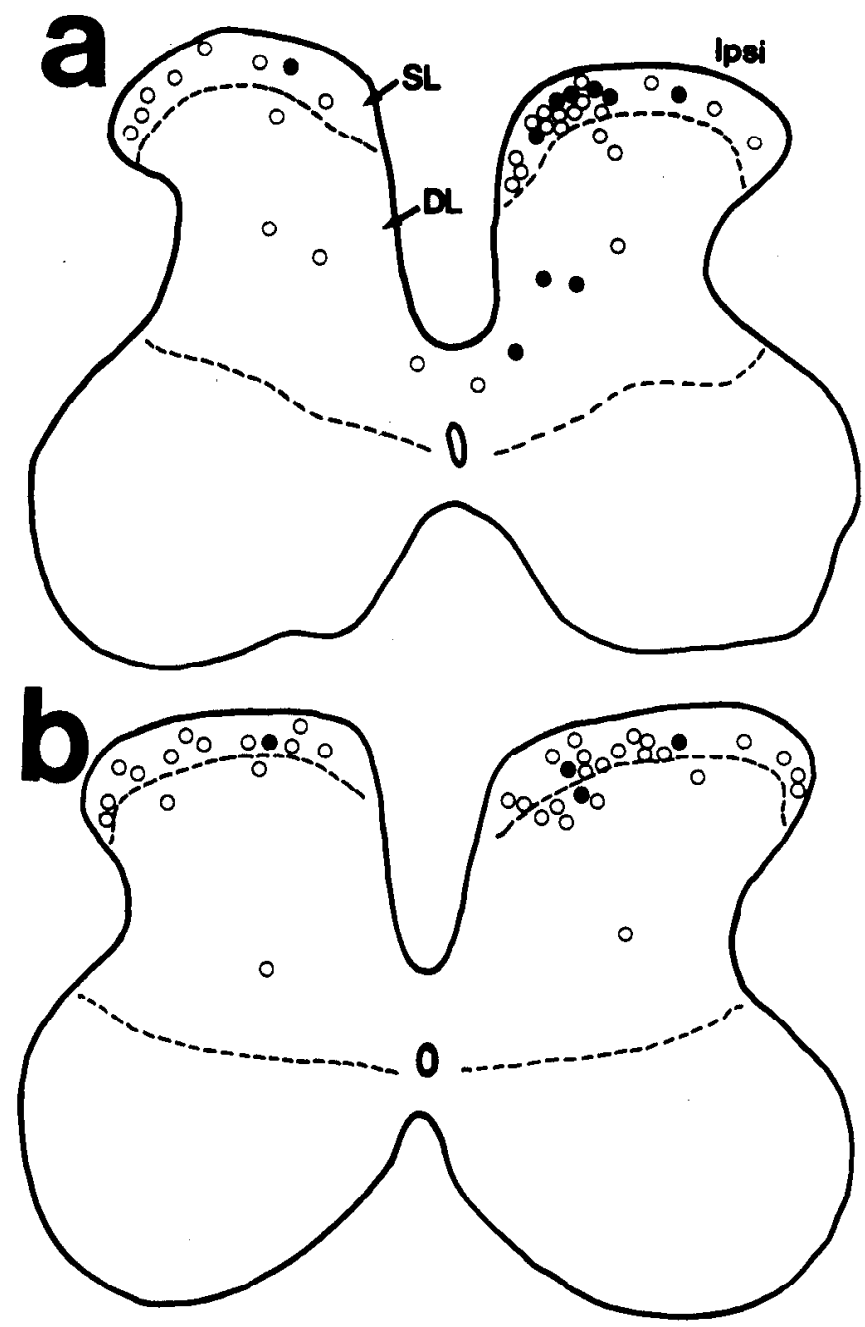

Figure 3. Camera lucida drawings of one $14-\mu \mathrm{m}$-thick section showing the distribution of NPY mRNA $(a)$ and NPY receptor (Y1) mRNA $(b)-$ positive neurons in the spinal dorsal horn (L4-L5). Neurons exhibiting markedly increased expression of these mRNAs (signal : noise ratio > 10) are represented with solid circles, and other positive neurons (signal : noise ratio $>5$ ) by open circles. Note that there is an increased expression in the ipsilateral side (Ipsi), especially the medial part of the spinal cord, as compared to contralateral side. $S L$, superficial layers (laminae I-II) of spinal dorsal horn; $D L$, deeper layers (laminae III-VI) of spinal dorsal horn. Each dot represents one neuron.

serum with $10^{-6} \mathrm{M}$ of NPY peptide (Peninsula, Belmont, CA), and by replacing the primary antiserum with normal serum (for Fos experiments).

\section{Results}

\section{NPY $m R N A$-positive neurons in the spinal cord}

In the L4-L5 segments of the spinal cord of control rats, NPY mRNA-positive neurons were mainly distributed in lamina II (Fig. 1 $a, b$ ). A few labeled neurons could also be seen in laminae I, III, V, and X. On the side contralateral to the inflammation, no significant change in NPY mRNA expression was found as compared to control animals (Fig. 1c,e,g). In the ipsilateral spinal cord inflammation induced a marked increase in the number of positive neurons. The increase was observed as early as $6 \mathrm{hr}$ after injection of adjuvant, and reached a peak at $3 \mathrm{~d}$, and the levels were back to normal at $7 \mathrm{~d}$ (Figs. 1, 2). The neurons with increased NPY mRNA levels were mainly concentrated in the medial part of lamina II in the dorsal horn (Figs. 1, 3). There 

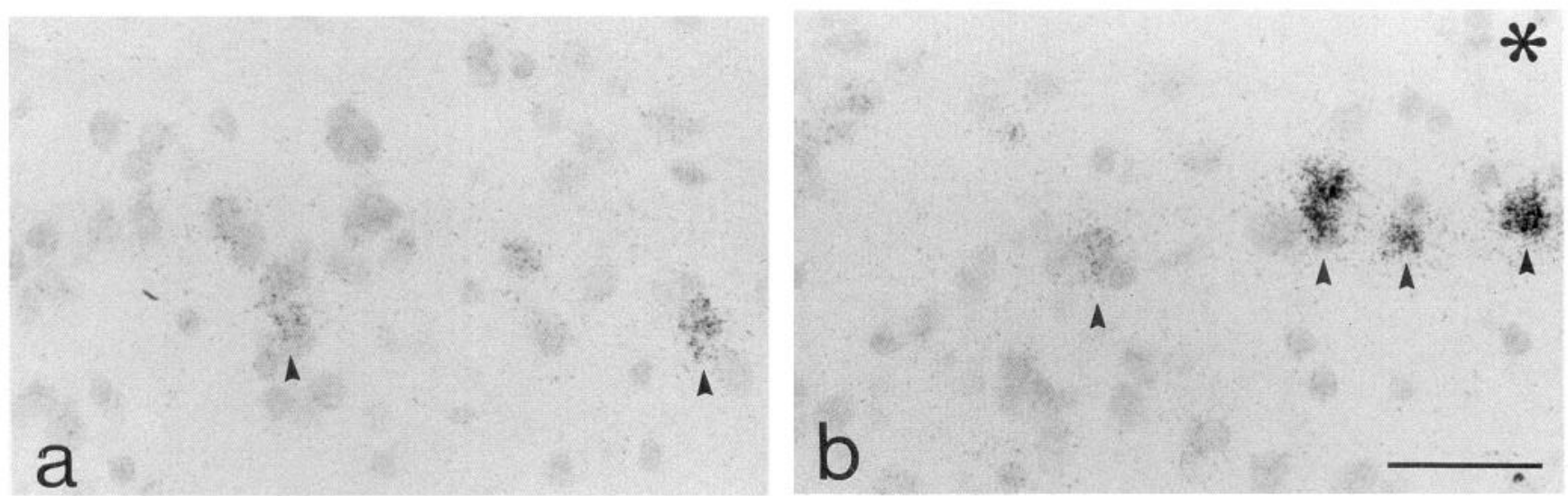

Figure 4. Bright-field micrographs showing the distribution of NPY mRNA-positive neurons in the medial part of the superficial layers of contralateral $(a)$ and ipsilateral $(b)$ spinal dorsal horn $3 \mathrm{~d}$ after unilateral inflammation. Both the number of positive neurons and the intensity of labeled neurons are enhanced on the ipsilateral side. Asterisks indicate the ipsilateral side. Scale bar, $50 \mu \mathrm{m}$.

was a $88 \%$ elevation $(P<0.001)$ in the number of NPY mRNApositive neurons in the ipsilateral side $3 \mathrm{~d}$ postinjection as compared to the contralateral side (Table 1). Furthermore the intensity of labeled cells was dramatically enhanced on the ipsilateral side (Fig. 4). When comparing only the strongly labeled neurons, the increase was even more pronounced (Fig. 3). For comparison, the elevation in the expression of dynorphin and enkephalin mRNA was monitored on adjacent sections from the ipsilateral spinal dorsal horn (Fig. 5). Three days after CFA injection, there was a $96 \%(P<0.01)$ and a $33 \%(P<0.01)$
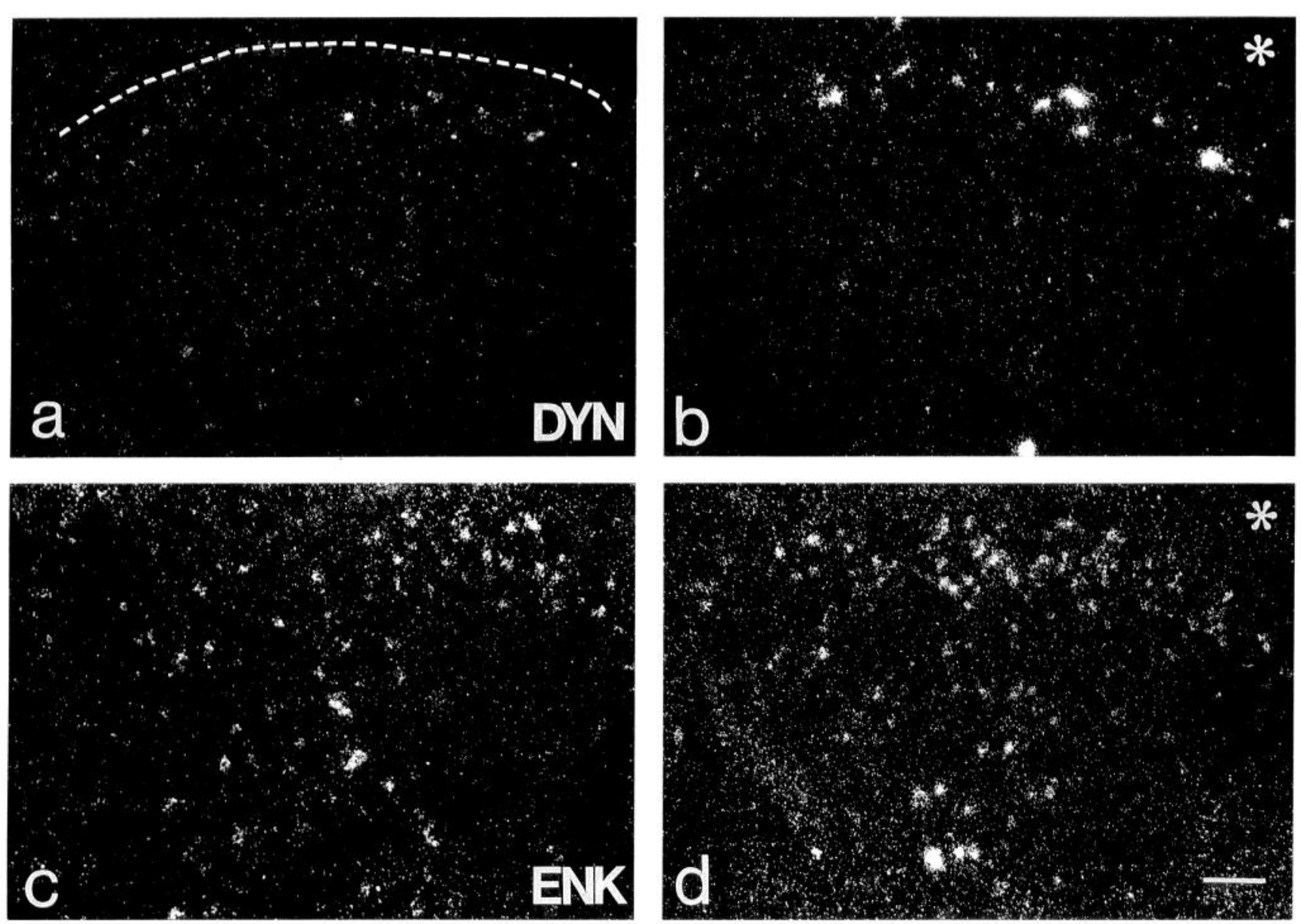

Figure 5. Dark-field photomicrographs showing the distribution of dynorphin $(D Y N ; a, b)$ and enkephalin $(E N K ; c, d)$ mRNA-positive neurons in the contralateral $(a, c)$ and ipsilateral $(b, d)$ spinal dorsal horn (L4-L5) $3 \mathrm{~d}$ after peripheral inflammation. Increases in the expression of mRNAs for both peptides can be seen on the ipsilateral side. Asterisks indicate the ipsilateral side. Dashed line indicates the boundary between gray and white matter in the dorsal horn. Scale bar, $100 \mu \mathrm{m}$. 
Table 1. Number of NPY, dynorphin, and enkephalin mRNApositive neurons in ipsilateral (Ipsi) and contralateral (Contra) spinal dorsal horn (L4-L5) 3 d after the injection of complete Freund's adjuvant into the hindpaw

\begin{tabular}{llll} 
& Contra & Ipsi & $\begin{array}{l}\text { \% In- } \\
\text { crease }\end{array}$ \\
\hline NPY & $16.2 \pm 0.9$ & $30.4 \pm 1.2^{* * *}$ & $88 \%$ \\
Dynorphin & $11.5 \pm 1.5$ & $22.5 \pm 2.4^{* *}$ & $96 \%$ \\
Enkephalin & $47.9 \pm 2.4$ & $63.6 \pm 3.4^{* *}$ & $33 \%$
\end{tabular}

Results are presented as the mean \pm SEM for 16 sections ( $14 \mu$ m thickness) taken from four rats (four sections/rat). Significance was examined by paired $t$ test. Adjacent sections were used for in situ hybridization of these three peptide mRNAs.

$* * p<0.01$.

$* * * p<0.001$

elevation in the number of mRNA-positive neurons for dynorphin and enkephalin, respectively (Table 1).

\section{NPY immunoreactivity in the spinal cord}

In control rats, only few NPY-immunoreactive (-IR) neurons were seen in a $14-\mu \mathrm{m}$-thick section. These neurons were mainly distributed in lamina II of the spinal dorsal horn. However, a dense network of NPY-IR fibers was observed particularly in laminae I-II, but also in the deeper laminae III-V and the central canal region. Peripheral inflammation caused an moderate increase in the number of NPY-IR neurons in the ipsilateral dorsal horn (Fig. $6 a-d$ ). These neurons were small and present in the medial part of lamina II. As shown in Table 2, there was a $56.8 \%$ increase $(P<0.01)$ in the ipsilateral dorsal horn as compared to the contralateral side. In addition, there was also an increase $(62.9 \%, P<0.05)$ in NPY immunoreactivity in the medial lamina II of the ipsilateral side (Table 2, Fig. $6 a-d$ ). In adjacent spinal sections CFA induced a marked increase in the number of c-Fos-positive neurons. These neurons were mainly located in the medial part of laminae I-II, as well as in lamina $\mathrm{V}$ in the ipsilateral dorsal horn. A few c-Fos-positive neurons were observed in laminae $\mathrm{I}-\mathrm{V}$ of the contralateral dorsal horn (Fig. $6 e, f$ ).

\section{$N P Y m R N A$ and NPY-immunoreactive neurons in $D R G$}

No NPY mRNA-positive or NPY-IR neurons were detected in the ipsilateral or contralateral L5 DRGs after CFA injection (Fig. $7 a-d$ ).

\begin{tabular}{|c|c|c|c|}
\hline & Contra & Ipsi & $\begin{array}{l}\% \text { In- } \\
\text { crease }\end{array}$ \\
\hline NPY-IR neurons & $16.9 \pm 1.7$ & $26.5 \pm 0.8^{* *}$ & $56.8 \%$ \\
\hline NPY-IR density & $100 \pm 10.5$ & $162.9 \pm 14.3^{*}$ & \\
\hline
\end{tabular}

Results are presented as number of positive neurons in eight sections (mean \pm SEM, $n=4$ ) and staining density from 20 sections (five sections/rat, $14 \mu \mathrm{m}$ thickness; $n=4$ ) (mean \pm SEM). Significance between the ipsilateral and contralateral sides was examined by paired $t$ test.

${ }^{*} p<0.05$.

$* * p<0.01$.
Table 3. Number of NPY receptor (NPYR) (Y1 subtype) mRNApositive neurons in the spinal dorsal horn (LA-L5) and percentage of Y1 mRNA-positive neurons in the dorsal root ganglia (DRG, L5 level) on ipsilateral (Ipsi) and contralateral (Contra) side $3 \mathrm{~d}$ after the injection of complete Freund's adjuvant into the hindpaw

\begin{tabular}{llll} 
& Contra & Ipsi & $\begin{array}{l}\% \text { In- } \\
\text { crease }\end{array}$ \\
\hline Spinal cord & $17.1 \pm 2.5$ & $27.5 \pm 2.5^{*}$ & $61 \%$ \\
DRG & $17.3 \pm 0.9 \%$ & $23.1 \pm 0.9 \% *$ & $34 \%$
\end{tabular}

Results are presented as the mean \pm SEM of 16 spinal cord sections taken from four rats (four sections/rat), and of 20 DRG sections taken from four rats (five sections/rat). Significant difference between the ipsilateral and contralateral sides was evaluated by paired $t$ test.

$* p<0.05$

\section{$N P Y$ (Y1) receptor $m R N A$-positive neurons in spinal cord}

In control rats, $\mathrm{Y} 1$ receptor $\mathrm{mRNA}$-positive neurons were mainly distributed in lamina II, but positive neurons could also be observed in deeper laminae (Fig. 8a,b). A marked elevation in the expression of $Y 1$ receptor $m R N A$ was found in the ipsilateral spinal dorsal horn 1 and $3 \mathrm{~d}$ following inflammation (Fig. $8 c$ $f)$. The increase in labeled neurons was mainly seen in the medial part of laminae II and III (Figs. $3 h, 8 d f$ ). There was a $59 \%$ increase $(P<0.05)$ in the number of $Y 1$ mRNA-positive neurons at $3 \mathrm{~d}$ in the ipsilateral spinal dorsal horn, as compared to the contralateral side (Table 3 ).

\section{$N P Y$ (Y1) receptor $m R N A-$ positive neurons in $D R G$}

Numerous Y1 receptor mRNA-positive neurons were found in the DRGs (L5) of control rats. The majority were small neurons. There was a significant elevation of $Y 1$ receptor $m R N A$ expression in the ipsilateral DRG $3 \mathrm{~d}$ after inflammation (Fig. $7 e, f)$. In the contralateral DRG, $17.3 \pm 0.9 \%$ (mean $\pm \mathrm{SEM}$ ) of the toluidine blue-positive cell profiles were $\mathrm{Y} 1$ receptor mRNA positive. The percentage increased to $23.1 \pm 0.9 \%(P$ $<0.05$ ) in the ipsilateral DRG (Table 3). There was no significant change in the size of neuron profiles, and most of them were still small ones with a size range from 250 to $450 \mu \mathrm{m}^{2}$ (Figs. $7 e, f ; 9 A, B$ ).

\section{Control experiments}

An excess of cold probe completely abolished the mRNA signal for peptides and the receptor. There was no positive immunohistochemical staining after peptide absorption or omission of the primary antisera.

\section{Discussion}

The present study shows that injection of CFA into the paw causes a rapid and marked increase in NPY peptide and NPY mRNA levels in the dorsal horn of spinal cord. A marked elevation of dynorphin and enkephalin mRNA level was also found in adjacent sections of spinal cord, confirming previous observations (Ruda et al., 1988; Noguchi ct al., 1989; Dubner and Ruda, 1992) and supporting the validity of our inflammatory model. It is worthwhile to point out that the enhancement of NPY mRNA appears as pronounced as that of dynorphin. The changes in peptide and in mRNA levels after inflammation were confined to the ipsilateral side, and therefore the noninjected side of spinal cord and DRG could be used as a control together with control rats, which is also consistent with many previous reports (Ruda et al., 1988; Noguchi et al., 1989; 

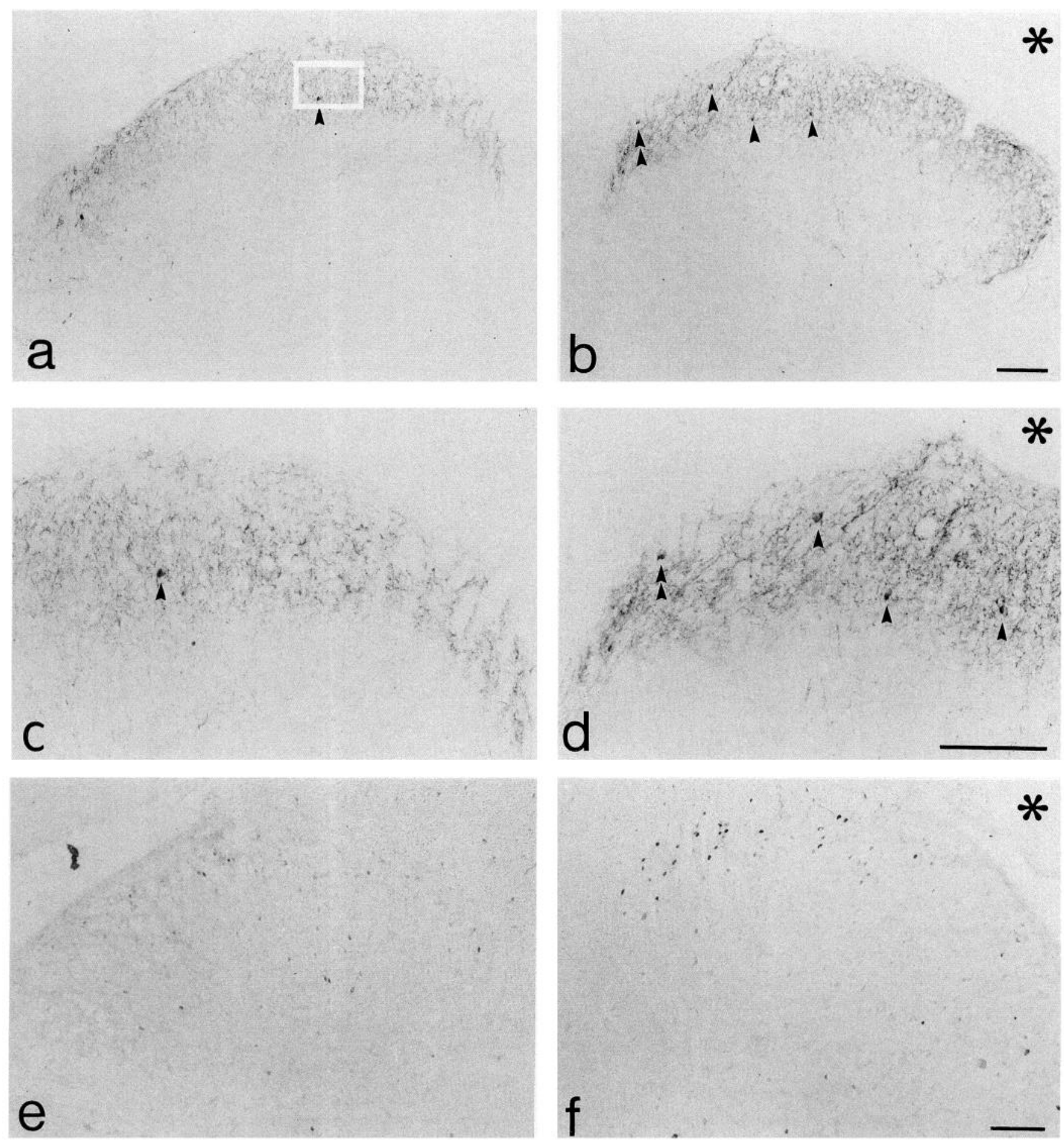

Figure 6. Bright-field photomicrographs showing the distribution of NPY-immunoreactive (-IR) $a-d)$ and c-Fos-IR $(e, f)$ neurons in contralateral $(a, c, e)$ and ipsilateral $(b, d, f)$ spinal dorsal horn (L4-L5) $3 \mathrm{~d}$ after inflammation. $c$ and $d$ are higher magnifications of $a$ and $b$ showing the medial superficial layers of spinal dorsal horn. An increase in the number of NPY-IR and c-Fos-IR neurons was found in the medial part of the superficial layers. Arrowheads indicate NPY-IR neurons in lamina II; double arrowhead indicates an NPY-IR neuron in the lamina I. Asterisks denote ipsilateral side. Square indicates the dorsal horn area where the staining intensity was measured. Scale bars, $100 \mu \mathrm{m}$.

Dubner and Ruda, 1992; Tokunaga et al., 1992; Hanesch et al., 1993). Finally, the increase in the expression of c-Fos protein in the ipsilateral laminae I, II, and V, where the majority of noxious primary afferents terminate and where dorsal horn nociceptive neurons predominate (Sugiura et al., 1986; Besson and Chaouch, 1987), further supports a long-lasting noxious stim- ulation and confirms several earlier studies (Hunt et al., 1987; Presley et al., 1990; Noguchi et al., 1991; Hylden et al., 1992; Leah et al., 1992).

The fact that both histochemical techniques, in situ hybridization and immunohistochemistry, revealed an increase in the number of cells on the inflammatory side strongly indicates that 

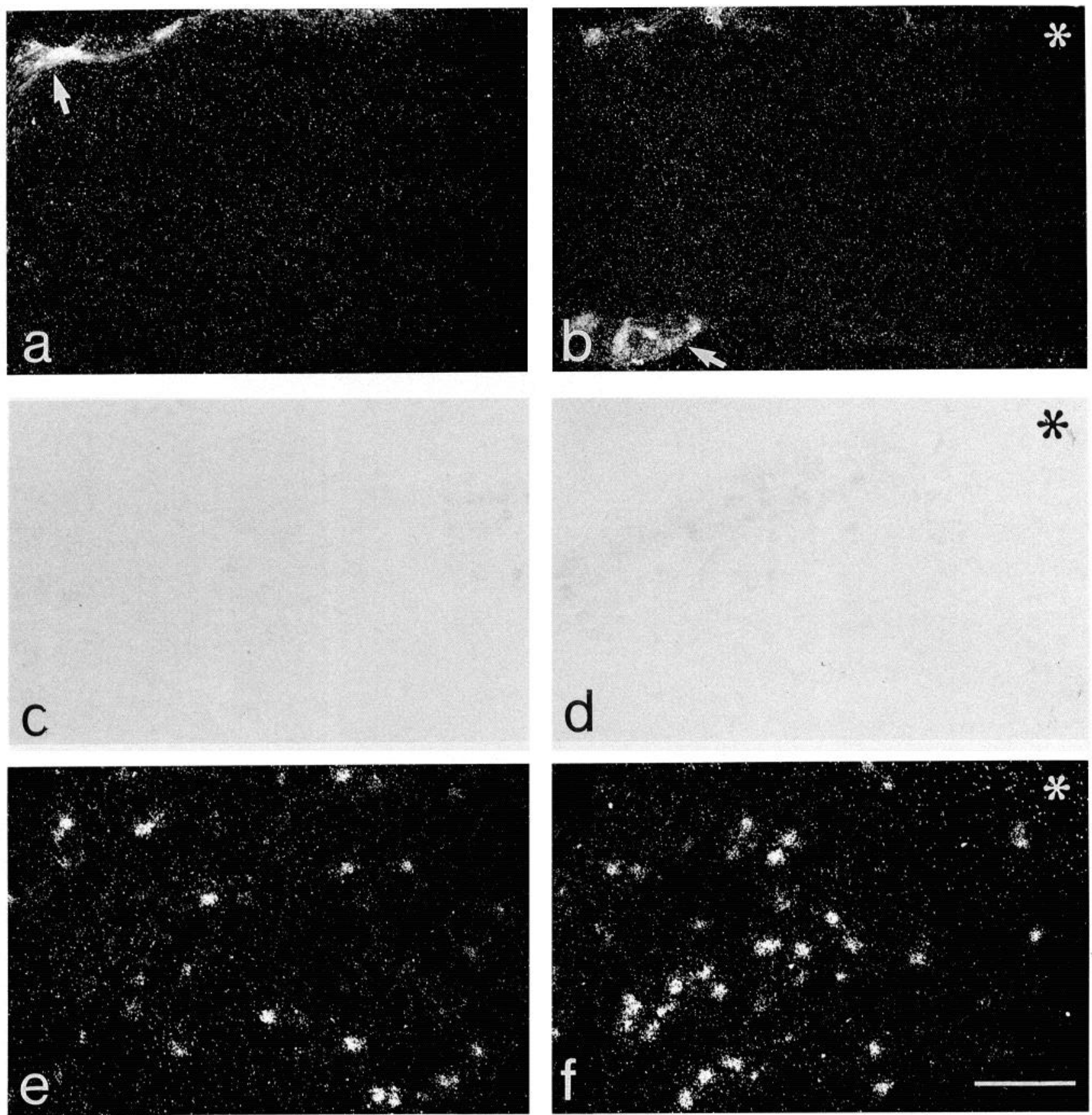

Figure 7. Dark-field $(a, b, e, f)$ and bright-field $(c, d)$ micrographs showing the distribution of NPY mRNA-positive $(a, b)$, NPY-immunoreactive $(c, d)$, and NPY (Y1) receptor mRNA-positive $(e, f)$ neurons in dorsal root ganglia (DRG) (L5) of contralateral $(a, c, e)$ and ipsilateral $(b, d, f)$ sides $3 \mathrm{~d}$ after inflammation. No NPY mRNA-positive or NPY-immunoreactive neurons are detected in any DRGs $(a-d)$. Inflammation induces an increase in NPY (Y1) receptor mRNA in small DRG neurons on the ipsilateral side $(e, f)$. Asterisks indicate the ipsilateral side; arrowheads indicate artifacts. Scale bar, $100 \mu \mathrm{m}$.

these cells indeed increase their synthesis of NPY peptide. The number of cells visualized with the two techniques was, however, not the same, which may reflect not only the sensitivity of the methodologies but also differences in the rate of transcription versus production of the mature peptide, or in the balance between synthesis and release of peptide. Furthermore, both increases occurred ipsilaterally in the spinal cord segments corresponding to the hindlimb dermatomes, and took place preferentially in the medial zone of the dorsal horn, which contains the somatopic projection from the various parts of the foot (Molander and Grant, 1985). However, no NPY mRNA or
NPY-immunoreactive neurons were found in the DRGs in either normal or inflammatory animals, in accordance with a previous study (Wakisaka et al., 1992), and in sharp contrast to the dramatic elevation of NPY mRNA and NPY immunoreactivity in DRG neurons after axotomy (Wakisaka et al., 1991, 1992; Zhang et al., 1993).

\section{Sources of NPY in the dorsal horn}

In the spinal cord, NPY-LI is present in high concentrations in the dorsal horn, especially in the substantia gelatinosa (Gibson et al., 1984; de Quidt and Emson, 1986). The most likely source 

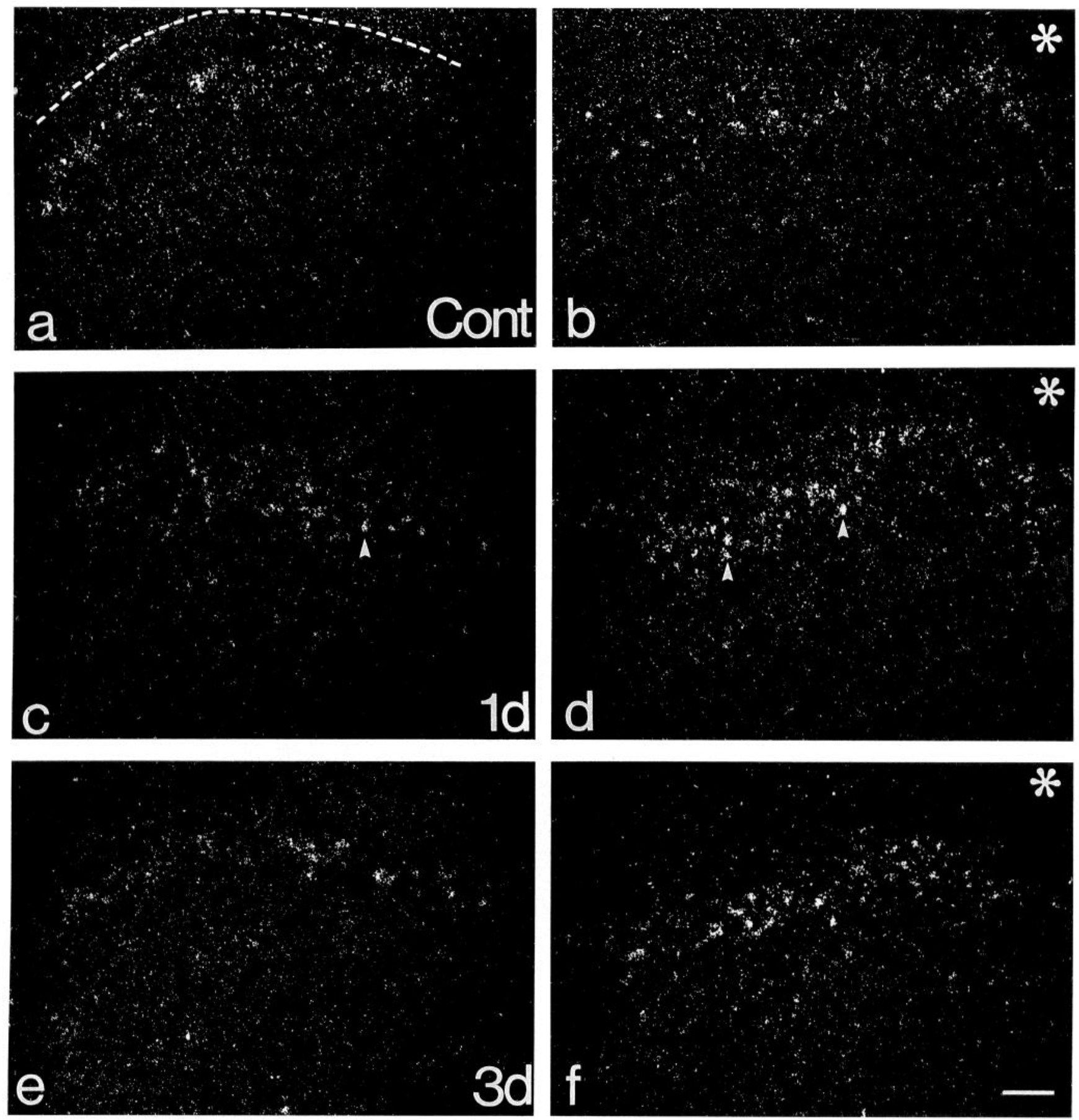

Figure 8. Dark-field micrographs showing the distribution of NPY (Y1) receptor mRNA-positive neurons in control $($ Cont; $a, b)$ and in contralateral $(c, e)$ and ipsilateral $(d, f)$ spinal dorsal horn (L4-L5) $1 \mathrm{~d}(1 d ; c, d)$ and $3 \mathrm{~d}(3 d ; e, f)$ after peripheral inflammation. There is a distinct elevation in the number of NPY (Y1) mRNA-positive neurons in the ipsilateral cord. Asterisks indicate the ipsilateral side. Dashed line indicates the boundary between gray and white matter in the dorsal horn. Scale bar, $100 \mu \mathrm{m}$.

for NPY in the dorsal horn is the numerous NPY-immunoreactive cell bodies in laminae I-III, especially in lamina II, giving rise to a dense NPY-immunoreactive fiber plexus in laminae I and II (Gibson et al., 1984; de Quidt and Emson, 1986; see also Hökfelt et al., 1981; Hunt et al., 1981a,b). A further possibility is that descending, bulbospinal systems may contain and release NPY. For example, it is known that a proportion of the noradrenergic locus coereulus neurons contain NPY-LI (Everitt et al., 1984), but only some of these neurons seem to project to the spinal cord (Holets et al., 1988). The local neurons were demonstrated early using an antiserum raised to avian pancreatic polypeptide (APP), and transection of the cord and dorsal rhizotomy failed to alter APP-LI, suggesting presence in local spinal neurons (Hökfelt et al., 1981; Hunt et al., 1981a,b). This view was further supported by the fact that NPY could not be demonstrated in primary sensory neurons (Gibson et al., 1984). The present demonstration of a strong upregulation of NPY synthesis and peptide levels in local dorsal horn neurons 

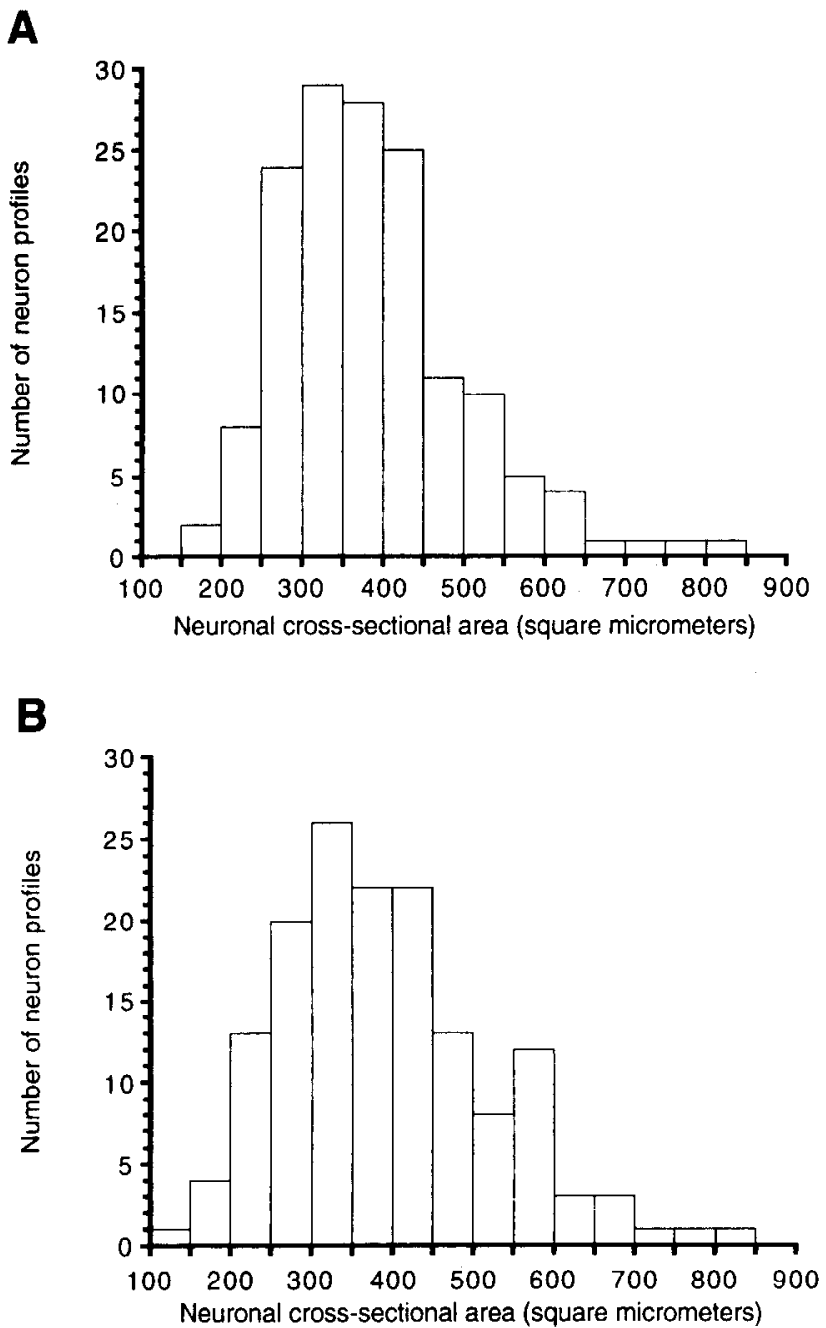

Figure 9. Size range of DRG neuron profiles in control $(A)$ and inflammatory groups $(B)$. For each group, 150 cells from four DRG sections (four rats) were measured.

further supports an involvement in pain related to inflammatory state. Whether or not NPY synthesis and peptide levels arc changed in supraspinal structures under inflammatory conditions remains to be determined. Therefore, it will be important to study whether or not descending systems or primary afferent fibers make synaptic contact with the NPY interneurons following inflammation.

\section{Comparison with axotomy}

The present results further underline the distinct difference in the response to, on the one hand, the inflammatory process (see Dubner and Ruda, 1992; Weihe et al., 1993) and, on the other hand, axotomy (see Hökfelt et al., 1994), both processes that result in pain (Wall and Devor, 1981; Devor, 1984). Thus, a very dramatic increase in NPY synthesis and peptide level was found in DRGs after axotomy (Wakisaka et al., 1991, 1992; Zhang et al., 1993). In contrast, no change in DRGs was detected following inflammation, as also shown by Wakisaka et al. (1992). Furthermore, sciatic nerve transection induced a decrease in levels of $Y 1$ receptor $m R N A$ in small DRG neurons (Zhang et al., 1994), whereas inflammation evoked an increase of Yl receptor mRNA-positive neurons in DRGs. Moreover, axotomy induced a shift in $\mathrm{Y} 1$ receptor $\mathrm{mRNA}$ expression from small to large neurons (Zhang et al., 1994), but such a shift was not observed after inflammation. In addition, there was no marked change in the expression of NPY and Y1 receptor mRNA in spinal cord after axotomy (Zhang et al., 1994), whereas in the present study inflammation induced a moderate upregulation of NPY peptide and Y1 receptor $m$ RNA in the spinal cord. In fact, Wakisaka et al. (1992) did not observe any effect on dorsal horn NPY-LI after CFA injection. Finally, inflammation-evoked upregulation of NPY mRNA in the dorsal horn disappeared in 1 week, whereas axotomy-evoked alterations in DRGs lasted at least for several weeks (Wakisaka et al., 1991; Zhang et al., 1993). It is important to note the transient nature of the CFAinduced inflammation in contrast to permanent effect of axotomy. Nevertheless, inflammation-induced changes seem mainly to be confined to the spinal cord level, whereas axotomy affects primary sensory neurons, indicating distinctly different mechanisms involved in the regulation of peptides. These changes may not only affect processing of nociception but may also be of importance for regenerative events, especially in the case of axotomy.

\section{Possible function of NPY}

A number of direct effects of NPY on DRG cells in vivo and in cultures have been demonstrated. NPY was found to inhibit $\mathrm{Ca}^{2+}$ currents in sensory neurons mediated via $\mathrm{G}_{0}$ protein, to stimulate the synthesis of inositol triphosphate and diacylglycerol, and to increase cytoplasmic free $\mathrm{Ca}^{2+}$ concentrations from an intracellular store (Ewald et al., 1988; Walker et al., 1988; Perney and Miller, 1989; Bleakman et al., 1991). Walker et al. (1988) have demonstrated high-affinity ${ }^{125}$ I-NPY binding sites on cultured DRG cells. Moreover, NPY could effectively inhibit the depolarization-evoked the release of SP from DRGs (Walker et al., 1988), as well as stimulation-induced release of SP from spinal cord (Duggan et al., 1991). More recently, further information on the mechanism of action of NPY has become available. NPY has been found to exert a presynaptic inhibition at sympathetic nerve terminals associated with a reduction in $\mathrm{Ca}^{2+}$ influx due to the selective inhibition of neuronal N-type $\mathrm{Ca}^{2+}$ channels (Toth et al., 1993). Furthermore, intrathecal injection of NPY causes a strong inhibition of spinal nociceptive reflexes in anaesthetised rats (Hua et al., 1991). Failure of opioid or $\alpha 2$ antagonists to alter the effect of NPY suggests that these receptors are not relevant to the antinociceptive effects of spinally administrated NPY (Hua et al., 1991). Using different fragments of NPY, it has been suggested that two subtypes of NPY receptor could modulate thermal and mechanical nociceptive transmission differentially (Hua et al., 1991). Clearly, antagonists would be important tools to elucidate the function of NPY in dorsal horn transmission under various experimental conditions, including inflammation.

Autoradiographic binding studies with ${ }^{125}$ I-PYY as ligand have shown a dense labeling in the superficial layers in the dorsal horn, and this binding is markedly reduced after capsaicin treatment, dorsal rhizotomy, and peripheral nerve section, suggesting that at least some of these NPY binding sites are located in the terminals of primary sensory afferents (Kar and Quirion, 1992). Our previous attempts to correlate the distribution of NPY Y1 receptor mRNA with various neuropeptides have shown a strong coexistence with SP mRNA in small sensory neurons in normal rats (Zhang et al., 1994), providing a further morphological basis for an interaction. 
Rowan et al. (1993) have recently shown that all NPY-immunoreactive cell bodies in laminae I-III of rat dorsal horn are GABA immunoreactive, and an increase in GABAergic and GABA levels has also been detected in the ipsilateral spinal cord following unilateral inflammation (Castro-Lopes et al., 1992). It is thus possible the dorsal horn interneurons may upregulate two coexisting messenger molecules, GABA and NPY, after peripheral inflammation. GABA nerve endings form axoaxonic contacts with primary afferent boutons (Barber et al., 1978; Todd and Lockhead, 1990), and $\mathrm{GABA}_{\mathrm{A}}$ and $\mathrm{GABA}_{\mathrm{B}}$ receptors are present on the central nerve endings of primary afferents (Singer and Placheta, 1980; Price et al., 1984). It may therefore be that NPY and GABA, in a concerted action via presynaptic effects, inhibit transmission in the dorsal horn. After inflammation this effect should be strengthened by the concomitant upregulation of $\mathrm{Y} 1$ receptors in many small primary sensory neurons, resulting in increased sensitivity to NPY released in the dorsal horn. Since inflammation also induced upregulation of sustance $P$ and CGRP in small sensory neurons (Noguchi et al., 1988; Hanesch et al., 1993), and since NPY (Y1) receptor mRNA colocalized with SP mRNA and CGRP mRNA (Zhang et al., 1994), the NPY released may counteract the noxious effect that the upregulated SP may exert in the dorsal horn. Finally, there was also a $\mathrm{Y} 1$ receptor $\mathrm{mRNA}$ upregulation in laminae II-III. How these neurons are involved in local circuitry is unknown and the functional significance remains to be evaluated.

\section{Concluding remarks}

Unilateral peripheral inflammation produced by injection of CFA into the hindpaw induces a distinct increase in the expression of NPY mRNA in the ipsilateral spinal dorsal horn. The upregulation that is also shown by immunohistochemical data is as dramatic as that for dynorphin mRNA. A significant increase in the expression of NPY (Y1) receptor was also found in the ipsilateral dorsal root ganglion (L5) and in the spinal dorsal horn after inflammation. These data strongly suggest that NPY and its Y1 receptor participate in the modulation of inflammation and nociception.

\section{References}

Allen JM, Koenig JI, eds (1992) Annals of the New York Academy of Science, Vol 611, Central and peripheral significance of neuropeptide Y and its related peptides. New York: New York Academy of Science.

Allen YS, Adrian TE, Allen JM, Tatemoto K, Crow TJ, Bloom SR, Polak JM (1983) Neuropeptide $Y$ distribution in rat brain. Science 221:877-879.

Barber RP, Vaughn JE, Saito K, McLaughlin BJ, Roberts E (1978) GABAergic terminals are presynaptic to primary afferent terminals in the substantia gelatinosa of the rat spinal cord. Brain Res 141:3555.

Besson JM, Chaouch A (1987) Peripheral and spinal mechanisms of nociception. Physiol Rev 67:67-186.

Bleakman D, Colmers WF, Fournier A, Miller RJ (1991) Neuropeptide $\mathrm{Y}$ inhibits $\mathrm{Ca}^{2+}$ influx into cultured dorsal root ganglion neurons of the rat via a Y2 receptor. Br J Pharmacol 103:1781-1789.

Castro-Lopes JM, Tavaras I, Tölle TR, Coito A, Coimbra A (1992) Increase in GABAergic cells and GABA levels in the spinal cord in unilateral inflammation of the hindlimb in the rat. Eur $J$ Neurosci 4:296-301.

Chronwall BM, DiMaggio DA, Massari VJ, Pickel VM, Ruggiero DA, O'Donohue TL (1985) The anatomy of neuropeptide Y-containing neurons in rat brain. Neuroscience 15:1159-1181.

Civelli O, Douglass J, Goldstein A, Herbert E (1985) Sequence and expression of the rat prodynorphin gene. Proc Natl Acad Sci USA $82: 4291-4295$.
Dagerlind $\AA$, Friberg K, Bean AJ, Hökfelt T (1992) Sensitive mRNA detection using unfixed tissue: combined radioactive and non-radioactive in situ hybridization histochemistry. Histochemistry 98:39-49. de Quidt ME, Emson PC (1986) Distribution of neuropeptide Y-like immunoreactivity in the rat central nervous system-II. Immunohistochemical analysis. Neuroscience 44:733-740.

Devor M (1984) The pathophysiology and anatomy of damaged nerve. In: Textbook of pain (Wall PD, Melzack R, eds), pp 49-64. New York: Churchill Livingston.

Dubner R, Ruda MA (1992) Activity-dependent neuronal plasticity following tissue injury and inflammation. Trends Neurosci 15:96103.

Duggan AW, Hope PJ, Lang CW (1991) Microinjection of neuropeptide $Y$ into the superficial dorsal horn reduces stimulus-evoked release of immunoreactive substance $P$ in the anaesthetized cat. Neuroscience 44:733-740.

Dumont Y, Martel J-C, Fournier A, St-Pierre S, Quiron R (1992) Neuropeptide $Y$ and neuropeptide $Y$ receptor subtypes in brain and peripheral tissues. Prog Neurobiol 38:125-167.

Eva C, Keinänen K, Monyer H, Seeburg P, Sprengel R (1990) Molccular cloning of a novel $G$ protein-coupled receptor that may belong to the neuropeptide receptor family. FEBS Lett 271:81-84.

Everitt BJ, Hökfelt T, Terenius L, Tatemoto K, Mutt V, Goldstein M (1984) Differential co-existence of neuropeptide Y (NPY)-like immunoreactivity with catecholamines in the central nervous system of the rat. Neuroscience 11:443-462.

Ewald DA, Matthies HJG, Perney TM, Walker MW, Miller RJ (1988) The effect of down regulation of protein kinase $C$ on the inhibitory modulation of dorsal root ganglion neuron $\mathrm{Ca}^{2+}$ currents by neuropeptide Y. J Neurosci 8:2447-2451.

Gibson JJ, Polak JM, Allen JM, Adrian TE, Kelly JS, Bloom SR (1984) The distribution and origin of a novel brain peptide, neuropeptide $Y$, in the spinal cord of several mammals. J Comp Neurol 227:7891.

Hancsch U, Pfrommer U, Grubb BD, Schaible H-G (1993) Acute and chronic phases of unilateral inflammation in rat's ankle are associated with an increase in the proportion of calcitonin gene-related peptideimmunoreactive dorsal root ganglion cells. Eur J Neurosci 5:154161.

Herzog H, Hort YJ, Ball HJ, Hayes G, Shine J, Selbie LA (1992) Cloned human neuropeptide $Y$ receptor couples to two different second messenger systems. Proc Natl Acad Sci USA 89:5794-5798.

Holets VR, Hökfelt T, Rökaeus A, Terenius L, Goldstein M (1988) Locus coeruleus neurons in the rat containing neuropeptide $\mathrm{Y}$, tyrosine hydroxylase or galanin and their efferent projections to the spinal cord, cerebral cortex and hypothalamus. Neuroscience 24:893906.

Howells RD, Kilpatrick DL, Bhatt R, Monham JJ, Poonian M, Udenfricnd $S$ (1984) Molecular cloning and sequence determination of rat preproenkephalin cDNA: sensitive probe for studying transcriptional changes in rat tissue. Proc Natl Acad Sci USA 81:7561-7565.

Hsu S-M, Raind L, Fanger H (1981) Use of avidin-biotin-peroxidase complex $(\mathrm{ABC})$ in immunoperoxidase technique. $\mathrm{A}$ comparison between $\mathrm{ABC}$ and unlabeled antibody (PAP) procedures. J Histochem Cytochem 29:577-580.

Hua XY, Boublik JH, Spicer MA, Rivier JE, Brown MR, Yaksh TL (1991) The antinociceptive effects of spinally administered neuropeptide $Y$ in the rat: systematic studies on structure-activity relationship. J Pharmacol Exp Ther 258:243-248.

Hunt SP, Emson PC, Gilbert R, Goldstein M, Kimmel JR (1981a) Presence of avian pancreatic polypeptide-like immunoreactivity in catecholamine and methionine-enkephalin containing neurons within the central nervous system. Neurosci Lett 21:125-130.

Hunt SP, Kelly JS, Emson PC, Kimmel JR, Miller RJ, Wu J-Y (1981b) An immunohistochemical study of neuronal populations containing neuropeptides or gamma-aminobutyrate within the superficial layers of the rat dorsal horn. Neuroscience 6:1883-1898.

Hunt SP, Pini A, Evan G (1987) Induction of c-fos-like protein in spinal cord neurons following sensory stimulation. Nature 328:632634.

Hylden JLK, Noguchi K, Ruda MA (1992) Neonatal capsaicin treatment attenuates spinal Fos activation and dynorphin gene expression following peripheral tissue inflammation and hyperalgesia. J Neurosci 12:1716-1725.

Hökfelt T, Lundberg JM, Terenius L, Jancso G, Kimmel J (1981) 
Avian pancreatic polypeptide (APP) immunoreactive neurons in the spinal cord and spinal trigeminal nucleus. Peptides 2:81-87.

Hökfelt T, Zhang X, Wiesenfeld-Hallin Z (1994) Messenger plasticity in primary sensory neurons following axotomy and its functional implications. Trends Neurosci in press.

Iadarola MJ, Brady LS, Draisci GRD (1988) Enhancement of dynorphin gene expression in spinal cord following experimental inflammation: stimulus specificity, behavioral parameters and opioid receptor binding. Pain 35:313-326.

Jazin EE, Zhang X, Söderström S, Williams R, Hökfelt T, Ebendal T, Larhammar D (1993) Expression of peptide YY and mRNA for the NPY/PYY receptor of the Y1 subtype in dorsal root ganglia during rat embryogenesis. Dev Brain Res 76:105-113.

Kar S, Quirion R (1992) Quantitative autoradiographic localization of [ $\left.{ }^{125} \mathrm{I}\right]$ neuropeptide $Y$ receptor binding sites in rat spinal cord and the effects of neonatal capsaicin, dorsal rhizotomy and peripheral axotomy. Brain Res 574:333-337.

Kimmel JR, Pollock HG, Hazelwood RL (1975) Isolation and characterization of a new pancreatic polypeptide hormone. J Biol Chem 250:9369-9376.

Larhammar D, Ericsson A, Persson H (1987) Structure and expression of the rat neuropeptide $Y$ gene. Proc Natl Acad Sci USA 84:20682072.

Larhammar D, Blomqvist AG, Yee F, Jazin E, Yoo H, Wahlestedt C (1992) Cloning and functional expression of a human neuropeptide Y/peptide YY receptor of the Y1 type. J Biol Chem 267:1093510938.

Leah JD, Sandkuhler J, Herdegen T, Murashov A, Zimmermann M (1992) Potentiated expression of Fos protein in the rat spinal cord following bilateral noxious cutaneous stimulation. Neuroscience 48: 525-532.

Lin TM, Chance RE (1974) Candidate hormones of the gut: bovine pancreatic polypeptide (BPP) and avian pancreatic polypeptide (APP). Gastroenterology 67:737-738.

Meyerhof W, Darlison MG, Richter D (1993) The elucidation of neuropeptide receptors and their subtypes through the application of molecular biology. In: New comprehensive biochemistry, Vol 25 (Huchos F, ed), pp 335-353.

Molander C, Grant G (1985) Cutaneous projection from the rat hindlimb foot to the substantia gelatinosa of the spinal cord studied by transganglionic transport of WGA-HRP conjugate. J Comp Neurol 237:476-484.

Mutt V, Fuxe K, Hökfelt T, Lundberg JM, eds (1989) Neuropeptide Y. New York: Raven.

Neugebauer V, Schaible HG (1990) Evidence for a central component in the sensitization of spinal neurons with joint input during development of acute arthritis in cat's knee. J Neurophysiol 64:299-311.

Noguchi K, Morita Y, Kiyama H, Ono K, Tohyama M (1988) A noxious stimulus induces preprotachykinin-A gene expression in the rat dorsal root ganglion: a quantitative study using in situ hybridization histochemistry. Mol Brain Res 4:31-35.

Noguchi K, Morita Y, Kiyama H, Sato M;Ono K, Tohyama M (1989) Preproenkephalin gene expression in the rat spinal cord after noxious stimuli. Mol Brain Res 5:227-234.

Noguchi K, Kowalski K, Traub R, Solodkin A, Iadarola MJ, Ruda MA (1991) Dynorphin expression and Fos-like immunoreactivity following inflammation induced hyperalgesia are colocalized in spinal cord neurons. Mol Brain Res 10:227-233.

Parker RMC, Fleetwood-Walker SM, Rosie R, Munro FE, Mitchell R (1993) Inhibition by $\mathrm{NK}_{2}$ but not $\mathrm{NK}_{1}$ antagonists of carrageenaninduced preprodynorphin mRNA expression in rat dorsal horn lamina I neurons. Neuropeptides 25:213-222.

Perney TM, Miller RJ (1989) Two different G-proteins mediate neuropeptide $\mathrm{Y}$ - and bradykinin-stimulated phospholipid breakdown in cultured rat sensory neurons. J Biol Chem 264:7317-7327.

Presley RW, Menetrey D, Levine JD, Basbaum AI (1990) Systemic morphine suppresses noxious-evoked Fos protein-like immunoreactivity in the rat spinal cord. J Neurosci 10:323-335.

Price GW, Wilkin GP, Turnbull MJ, Bowery NG (1984) Are baclofensensitive $\mathrm{GABA}_{\mathrm{B}}$ receptors present on primary afferent terminals of the spinal cord? Nature 307:71-74.

Rowan S, Todd AJ, Spike RC (1993) Evidence that neuropeptide Y is present in GABAergic neurons in the superficial dorsal horn of the rat spinal cord. Neuroscience 53:537-545.
Ruda MA, Iadarola MJ, Cohen LV, Young WSI (1988) In situ hybridization histochemistry and immunocytochemistry reveal an increase in spinal dynorphin biosynthesis in rat model of peripheral inflammation and hyperalgesia. Proc Natl Acad Sci USA 85:622-626.

Schäfer MKH, Nohr D, Krause JE, Weihe E (1993) Inflammationinduced upregulation of NK1 receptor mRNA in dorsal horn neurones. Neuroreport 4:1007-1010.

Schalling M (1990) In situ hybridization studies on regulatory molecules in neural and endocrine tissue with special reference to expression of coexisting peptides. MD thesis, Karolinska Institute, Stockholm.

Singer E, Placheta $P$ (1980) Reduction of $\left[{ }^{3} \mathrm{H}\right]$ muscimol binding sites in rat dorsal spinal cord after neonatal capsaicin treatment. Brain Res 202:484-487.

Sluka KA, Dougherty PM, Sorkin LS, Willis WD, Westlund KN (1992) Neural changes in acute arthritis in monkeys. III. Changes in substance $P$, calcitonin gene-related peptide and glutamate in the dorsal horn of the spinal cord. Brain Res Rev 17:29-38.

Solodkin A, Traub RJ, Gebhart GF (1992) Unilateral hindpaw inflammation produces a bilateral increase in NADPH-diaphorase histochemical staining in the rat lumbar spinal cord. Neuroscience 51: 495-499.

Sugiura Y, Lee CL, Perl ER (1986) Central projections of identified, unmyelinated $(C)$ afferent fibres innervating mammalian skin. Science 234:358-361.

Tatemoto K (1982) Neuropeptide Y; complete amino acid sequence of the brain peptide. Proc Natl Acad Sci USA 79:5485-5489.

Tatemoto K, Carlquist M, Mutt V (1982) Neuropeptide Y, a novel brain peptide with structural similarities to peptide $Y Y$ and pancreatic polypeptide. Nature 296:659-660.

Todd AJ, Lockhead V (1990) GABA-like immunoreactivity in type I glomeruli of rat substantia gelatinosa. Brain Res 514:171-174.

Tokunaga A, Senba E, Manabe Y, Shida T, Ueda Y, Tohyama M (1992) Orofacial pain increases mRNA level for galanin in the trigeminal nucleus caudalis of the rat. Peptides 13:1067-1072.

Toth PT, Bindokas VP, Bleakman D, Colmers WF, Miller RJ (1993) Mechanism of presynaptic inhibition by neuropeptide $Y$ at sympathetic nerve terminals. Nature 364:635-639.

Wahlestedt C, Reis DJ (1993) Neuropeptide Y-related peptides and their receptors-are the receptors potential therapeutic drug targets? Annu Rev Pharmacol Toxicol 32:309-352.

Wakisaka S, Kajander KC, Bennett GJ (1991) Increased neuropeptide Y (NPY)-like immunoreactivity in rat sensory neurons following peripheral axotomy. Neurosci Lett 124:200-203.

Wakisaka S, Kajander KC, Bennett GJ (1992) Effects of peripheral nerve injuries and tissue inflammation on the levels of neuropeptide Y-like immunoreactivity in rat primary afferent neurons. Brain Res 598:349-352.

Walker MW, Ewald DA, Perney TM, Miller RG (1988) Neuropeptide $Y$ modulates neurotransmitter release and $\mathrm{Ca}^{2+}$ currents in rat sensory neurons. J Neurosci 8:2438-2446.

Wall PD, Devor M (1981) The effect of peripheral nerve injury on dorsal root potentials and on transmission of afferent signals into the spinal cord. Brain Res 209:95-111.

Weihe E, Schäfer MKH, Nohr D, Persson S (1994) Exprcssion of neuropeptides, neuropeptide receptors and neuropeptide processing enzymes in spinal neurons and peripheral non-neural cells and plasticity in models of inflammatory pain. In: Neuropeptides, nociception and pain (Schmidt R, Schaible HG, eds), in press.

Young III WS (1990) In situ hybridization histochemistry. In: Handbook of chemical neuroanatomy, $\mathrm{Vol} 8$, Analysis of neuronal microcircuits and synaptic interactions (Björklund $A$, Hökfelt T, Wouterlood FG, Van Den Pol AN, eds), pp 481-512. Amsterdam: Elsevier.

Zhang X, Meister B, Elde R, Verge VMK, Terenius L, Hökfelt T (1993) Large calibre primary afferent neurons projecting to the gracile nucleus express neuropeptide $\mathrm{Y}$ after sciatic nerve lesions: an immunohistochemical and in situ hybridization study in rats. Eur J Neurosci 5:1510-1519.

Zhang X, Wiesenfeld-Hallin Z, Hökfelt T (1994) Effect of pcripheral axotomy on expression of neuropeptide $Y(Y 1)$ receptor mRNA in rat lumbar dorsal root ganglia. Eur J Neurosci 6:43-57.

Zimmermann M (1983) Ethical guidelines for investigations of experimental pain in conscious animals. Pain 16:109-110. 